\section{Lessons From a Tiny Strand of RNA}

A s I write, we are at war with a microscopic enemy that has created global havoc, taken thousands of lives, and will undoubtedly leave us in economic distress for a long time to come. I wish it was a prettier picture. I had hoped I could say that by the time you read this, the crisis will be a distant memory, but projections suggest otherwise. At best, the damage from the enemy will be lessening.

As I look out my window in a high-rise in San Francisco, I can see that construction workers are absent from unfinished buildings, the sidewalks are nearly empty, and at a time when streets are often bumper-to-bumper, I count 6 cars and a bus. At the same time, I look out at the beautiful San Francisco Bay and realize that I can see it and everything else very clearly. Pollution is decreasing and the skies and waters are clearing. I have been thinking about what this crisis might teach us. For surely something good must emerge.

I think the biggest take-home message is that lack of a unified health system only complicates matters. It's clear that preparedness for this crisis in our health system, including public health, was uneven across the country and perhaps even within states. The need for protective equipment like gowns, gloves, and respirators quickly exhausted supply in areas such as New York, not to mention the need for ICU beds and ventilators. In a national healthcare crisis, shouldn't the federal government be able to provide the equipment that patients and providers need either from federal stockpiles or by redistributing from sites more abundantly equipped? Of course it should. Hopefully, this lesson will create a process for this in the future. We can't go forward pretending a crisis won't occur again.

A more positive lesson is that we've all learned how to do telemedicine and to work from home as much as possible. And we are holding virtual meetings that don't require us to get on a plane. I think this will stick. It's better for the environment. It's efficient and less expensive. And many patients love telemedicine. There is nothing worse when you feel sick than dragging yourself out to the doctor. With advances in digital health, we should soon be able to equip patients with devices to get vitals and to provide home delivery and pick-up of fingerstick blood drops and other samples. Think about it: we already do this for DNA testing in colon cancer diagnostics. Why not broaden these opportunities? Of course, we will need to shift how doctors are reimbursed for caring for patients, but we can figure it out.

Finally, I think the public has learned a lot about infection control. More than ever, people will sneeze properly into their elbows, wash their hands while singing "Happy Birthday" twice, stop touching their faces, and stay home when they are sick. I would venture to say that we will see fewer deaths next year from influenza likely because the public will practice better hygiene than before.

Forgive me for not writing about cancer this month. COVID-19 has pretty much taken over my thoughts. But we asked our colleagues from the NCCN Best Practices Committee to provide some advice about safety for you and your patients, so please take time to read this month's Special Feature titled, "Safety at the Time of the COVID-19 Pandemic: How to Keep Our Oncology Patients and Healthcare Workers Safe."

\section{Reference}

1. Cinar $P$, Kubal T, Freifeld A, et al. Safety at the time of the COVID-19 pandemic: how to keep our oncology patients and healthcare workers safe. J Natl Compr Canc Netw 2020;18:504-509.

WHAT DO YOU THINK? To submit a Letter to the Editor, email JNCCN@nccn.org or log into www.editorialmanager.com/JNCCN.

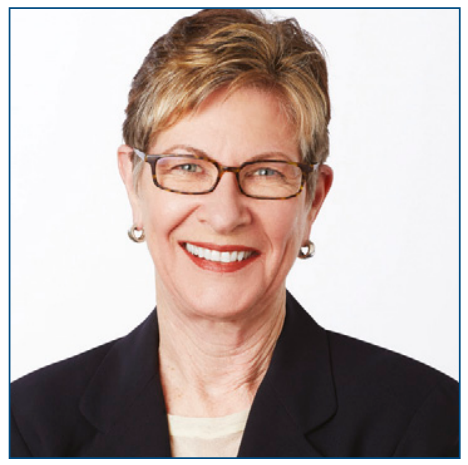

MARGARET TEMPERO, MD

Margaret Tempero, MD, is a Professor of Medicine and Director of the UCSF Pancreas Center and editor-in-chief of JNCCN. Her research career has focused on pancreatic ductal adenocarcinoma, especially in the area of investigational therapeutics. Dr. Tempero has served on the ASCO Board of Directors and as ASCO President. She currently serves on the ASCO Conquer Cancer Foundation Board. She codirected the AACR/ASCO Methods in Clinical Cancer Research and taught this course and similar courses in Europe and Australia. She was founding Chair of the $\mathrm{NCl}$ Clinical Oncology Study Section and served as a member and Chair of the $\mathrm{NCl}$ Board of Scientific Counselors Subcommittee A. She is a member of the Scientific Steering Committee and Chair of the Clinical and Translational Study Section for the Cancer Prevention \& Research Institute of Texas. She is or has been on the Scientific Advisory Boards of the Lustgarten Foundation, the Pancreatic Cancer Action Network, the V Foundation, The Alberta Canada Cancer Board, and the EORTC. She served as a member of the Oncology Drug Advisory Committee for the FDA. She has served as Deputy Director and Interim Director for the UNMC Eppley Cancer Center. She is Chief Emeritus of the Division of Medical Oncology at UCSF. She served as the founding Deputy Director and was later Director of Research Programs at the UCSF Helen Diller Family Comprehensive Cancer Center.

doi: $10.6004 /$ jnccn.2020.0023

The ideas and viewpoints expressed in this editorial are those of the author and do not necessarily represent any policy, position, or program of NCCN. 